\title{
doispontos:
}

\section{Self-governance and reform in Kant's liberal republicanism - ideal and non-ideal theory in Kant's Doctrine of Right}

\author{
Helga Varden \\ helga.vargen@gmail.com \\ University of Illinois, Urbana-Champaign, EUA
}

\begin{abstract}
At the heart of Kant's legal-political philosophy lies a liberal, republican ideal of justice understood in terms of private independence (non-domination) and subjection to public laws securing freedom for all citizens as equals. Given this basic commitment of Kant's, it is puzzling to many that he does not consider democracy a minimal condition on a legitimate state. In addition, many find Kant ideas of reform or improvement of the historical states we have inherited vague and confusing. The aim of this paper is to untangle both puzzles by exploring Kant's idea of self-governance. I argue that Kant's idea of self-governance gives us a very good starting point for thinking about how to leave room for a variety of political systems-different ideals-that have grown out of and responding to different contingent historical and cultural circumstances. It also helps us identify those areas where we want to take extra care to build in safeguards to secure stability and to take sufficiently seriously humankind's truly nasty sides.
\end{abstract}

Keywords: self-government; republicanism; ideal; history.

\section{Auto-governo e reforma no republicanismo liberal de Kant - teoria ideal e não-ideal na Doutrina do Direito}

Resumo: No coração da filosofia politico-jurídico de Kant repousa um ideal de justiça liberal, republicano, compreendido em termos de independência privada (não-dominação) e submissão a leis públicas que garantem a liberdade de todos os cidadãos como iguais. Dado esse compromisso básico de Kant, é algo que chama a atenção de muitos o fato dele não considerar a democracia como uma condição mínima de um estado legítimo. Além disso, muitos consideram que as ideias de Kant sobre reforma e melhoria do estado histórico que herdamos são ideias vagas e confusas. Argumento que a ideia de Kant de autogoverno nos fornece um ótimo ponto de partida para pensarmos o modo de como deixar espaço para uma variedade de sistemas políticos - diferentes ideais - que surgem e respondem a diferentes contextos históricos e circunstâncias culturais. Ela também nos ajuda a identificar aquelas áreas a que queremos dedicar um maior esforço no sentido de construir garantias de modo a assegurar estabilidade e nos ajuda, também, a levar a sério aquelas dimensões humanas verdadeiramente nefastas.

Palavras-chave: autogoverno; republicanismo; ideal; história.

\section{INTRODUCTION ${ }^{1}$}

At the heart of Kant's legal-political philosophy lies a liberal, republican idea of justice understood in terms of private independence (non-domination) and instead subjection to public, universal laws securing freedom for all as equals. In fact, our only innate, inalienable right is seen as our right to freedom-a right 
Kant in his key work on justice, the Doctrine of Right, defines as a person's right to "independence from being constrained by another's choice... insofar as it [one's exercise of freedom] can coexist with the freedom of every other in accordance with a universal law." (MM 6: 237, cf. 317) ${ }^{2}$ Time and time again, and throughout this work, Kant emphasizes that freedom is "the principle and indeed the condition for any exercise of coercion" (MM 6:340) - making rightful coercion the "hindering of a hindrance to freedom in accordance with a universal law" (MM 6:231) and the just state one in which "law itself rules and depends on no particular person." (MM 6: 340, cf. 316) Despite agreement among scholars that any plausible interpretation of Kant's theory of justice has to view these ideas as central to it, much interpretive disagreement persists with regard to what kind of theory of justice and rights we should attribute to him or the Kantian project. The suggestions span from rightwing libertarianism (BYRD; HRUSCHKA, 2012) to legal positivism ${ }^{3}$ - with pretty much all the positions in between, including Rawlsian (GUYER, 2000) and need-based, welfarist (KAUFMAN, 1999; O'NEILL, 1996, 2000) liberalisms. In my view, Kant's liberal republicanism is distinct from all of these other positions, though it incorporates important ideas typically advanced by them. ${ }^{4}$ Yet rather than engaging these, by now, more well trodden disagreements among prominent interpretations in much detail, this paper's main aim is to attend to an issue that till date has received much less explicit discussion among Kant scholars, namely the issue of what conception of self-governance Kant defends.

My suggestion below is Kant's idea of self-governance in the liberal republic can be specified by means of three complementary ideas: (i) The public authority as a tripartite, representative authority, whose reasoning can understood as legal-political reasoning within the parameters set by the citizens' basic private and public rights and duties; (ii) free public debate (among all citizens as participants in public debates, including scholarly debates) within the parameters of free speech (including freedom of assembly and association and freedom of press); and, finally, (iii) reform of the public institutions over time so as to make it possible for any citizen (regardless of socio-economic starting point) to become an active member of the republic (active citizenship) and to work her or his way into any public position, including by ridding the offices of the public authority of appointments tracking inheritance and replacing them with merit-based evaluations. Exactly how particular societies go about realizing this idea of public representation and participation - which particular ideal they will be working out - will and should vary somewhat, depending on considerations of prudence and historical circumstances.

To address the topic of self-governance in Kant's philosophy of right we must deal with several tricky interpretive and philosophical questions. More specifically, we need to address passages where Kant discusses issues such as the three possible forms of the state (autocracy, aristocracy, and democracy); the four different ways in which force, freedom, and law can be combined in the exercise of power in any particular state (anarchy, despotism, barbarism, and republic); the distinction between passive and active citizenship; the notion of citizens governing themselves through what Kant calls "public" and "private" reason; and, finally, the idea of imperfect, but minimally just states reforming themselves into well-functioning republics. Kant does give some suggestions as we set out to do this, but some of this work Kant explicitly and deliberately left behind for those coming after him. At the end of the "Preface" to the Doctrine of Right, Kant explains that he has

... worked less thoroughly over certain sections [dealing with public right] than might be expected in comparison with the earlier ones [dealing with private right], partly because it seems to me that they can be easily be inferred from the earlier ones and partly, too, because... [they] are currently subject to so much discussion, and still so important, that they can well justify postponing a decisive judgment for some time. (MM 6: 209) 
An idea informing this paper is that "some time" has passed now, and hence it is easier to make a few more suggestions regarding the structure of the public (legal-political) institutions comprising a just state than Kant himself did. The projects of trying to realize freedom-based legal-political institutional systems are not at as nascent a stage as they were at Kant's time and with the help of Kant's insights on the matter we can identify important elements of more successful, more recent developments in liberal, legal-political systems to help us clarify what it is that they and we, as citizens of such states, have been or are doing when things have gone well. Hence, my basic stance is that Kant gives us an extremely good starting point for thinking about our liberal legal-political structures, including how to improve or reform them in good ways. His approach also helps us identify where we want to leave quite a bit of space for variation between different systems due to their different particular histories and circumstances, and where we want to be particularly cautious and build extra safeguards in a prudential effort to take sufficiently seriously worries concerning stability as well as humankind's truly nasty sides.

The paper is structured in the following way: Part One ("Kant's Theory of Domestic Right - a Sketch") starts by outlining the main strands of interpretation regarding core arguments of Kant's concerning private and public right before briefly identifying what I take to be characteristic of the stronger readings. Then, in Part Two ("Self-Governance and Reform") the focus is on the interpretive and philosophical issues concerning what Kant considers to be the first part of public right, namely the right of the state (public right) and the specific issues here that are important to clarify as we seek to understand Kant's ideas of self-governance, including the very important role the ideas of public representation, free public discussion, and social mobility play in his vision of how states realize ideals of the idea of the "true" republic in our non-ideal world through institutional reform. I then proceed to defend Kant's basic framework, arguing that part of its strength concerns the way in which the ideal (freedom based) principles set the framework within which the non-ideal (prudential and historically contingent or particular) considerations are given due consideration. This approach makes the idea of the just state imaginable as "stable for the right reasons," to borrow Rawls's useful term, and it makes it easier to identify and rectify possible mistakes made not only by Kant, but also by our current legal-political practices.

\section{PART I: KANT'S THEORY OF DOMESTIC RIGHT - A SKETCH}

Right, or justice, Kant suggests, concerns interaction in space and time. Before and unless there is interaction involving external (spatio-temporal) force - what Kant call's external uses of freedom-there is at most only virtue. Only once we interact in ways that can directly affect (spatio-temporally interfere with) one another's ability to set and pursue ends of our own does right as an issue arise. Those aspects of our actions, like their maxims and moral motivation that make actions virtuous_-give them what Kant sometimes calls "moral worth" and involve exercises of "internal freedom"-are beyond the grasp of spatio-temporal means, or coercion. Indeed, anything that does not have spatio-temporal force, such as most uses of words, regardless of how mean, hurtful, or stupid they are, will not be criminalized in a just state. The absence of virtue cannot be criminalized because one cannot reach virtue (internal freedom) by the spatio-temporal means of the law (coercion, or external freedom) and because lacking virtue, as such, is not to wrong anyone else from the point of view of right (justice); to lack in virtue is not coercively to deprive others of their ability to act freely in the world. ${ }^{5}$ The only justifiable restrictions on interactions are those that can be imposed in the name of freedom, meaning that they are necessary to make reciprocal freedom under universal law possible for interacting persons. 
So which restrictions are justifiable from the point of view of right? Because we are embodied persons, Kant starts, from the external point of view of right, the relation between our bodies and our persons must be regarded as analytic in nature. From the point of view of space and time, that is, there is no discernible distinction between one's body and one's person, which is why, for example, unauthorized touching of another's body is to commit battery. Hence, Kant concludes, since we have an innate right to freedom, we must also be seen as having an innate right to our own bodies (MM 6: 249). ${ }^{6}$ The next step is to explain how we can acquire rights with regard to things distinct from us, or separate from our bodies. Kant's theory of private right is an account of this (of acquired, private right), namely of how we go about obtaining normative, enforceable claims to things distinct from us, such that no wrong is being done when these claims are enforced whereas wrong is being done when they are disrespected. Kant proposes that there are three kinds of objects with regard to which we make normative ownership claims on each other, namely things ("my" car), others' services (you "owe" me five hours of work), and other persons ("my" child) — and this is why we have three categories of private right: private property right, contract right, and status right (right involving claims to other people, such as family right). According to Kant, in the state of nature (in a pre-state condition) our claims to these three kinds of things remain "provisional," and only in a civil condition do they become "conclusive" rights. Conclusive rights are only possible through the establishment of a public authority-meaning an artificial legal-political authority that represents each and all of us (and yet no one in particular) — within the institutional parameters of which we interact as private persons. ${ }^{7}$

In addition to disagreements concerning how to understand each of the three principles of private right, there is much disagreement in the literature about Kant's claim that in the state of nature individuals' rights remain "provisional," and some of these disagreements can be seen as separating the interpretations into the "libertarian," "legal positivist," "liberal republican" etc. traditions. This disagreement concerning the provisionality of private right in the state of nature includes a dispute regarding Kant's answer to the question of why we need the state (the establishment of a public authority): is it merely for prudential reasons, for ideal reasons, or for some other reasons? In other words, what is it that the state (the public authority) can do that private individuals cannot do such that the state of nature is not, whereas civil society is a condition in which "conclusively" rightful relations are realizable; why, exactly, is right or justice unrealizable in the state of nature and realizable only within the public, legal-political institutional framework of civil society (the state)? What are, that is to say, (the nature of) the problems in the state of nature that the establishment of civil society is a solution to? The more careful interpretations here aim to tie their accounts of Kant's idea of the state being necessary to conclude rights to Kant's claims that although the state of nature does not need to be "a state of injustice... it would still be a state devoid of justice" (MM 6:312) and that people who choose to stay in the state of nature and solve their disputes by feuding "do one another no wrong... but in general... do wrong in the highest degree by willing to be and to remain in a condition that is not rightful” (MM 6: 307).

On the prudential readings, the state is needed to safeguard us against our tendency to act in evil manners, or to deal with problems issuing from our "warped wood." In contrast, on the ideal interpretations, the state does more than this: state is either seen as also solving certain ideal problems of assurance or as also solving such ideal problems of assurance in addition to solving certain ideal problems of indeterminacy regarding the general specification (positing) and particular specification (application) of the principles of private right. ${ }^{9}$ What is common on all the ideal readings is the idea that for Kant rightful force is impossible in the state of nature, including if we assume only virtuous intentions among the people finding themselves interacting in this condition. And without the possibility of rightful force, there is no justice since then there are no rightful, enforceable solutions even to reasonable disagreements that can occur among the interacting persons. 
Regardless of the various interpretations' take on the question of why we need the state, the next issue they all must handle is what Kant envisions the state-the basic public legal-political authority or institutional framework-to look like. This is the topic of the second part of Kant's account of domestic justice, which is his account of domestic public right ("The Right of a State"). And while his account of private right is limited to private persons' claims on one another, the account of domestic public right concerns citizens' claims on their public institutions. Kant starts his discussion of domestic public right by clarifying that the concept refers to "The sum of the laws which need to be promulgated generally in order to bring about a rightful condition." (MM 6:311) Shortly thereafter he continues by explaining that the moral idea of the public authority (the state)

consists of three persons...: the sovereign authority... in the person of the legislator; the executive authority in the person of the ruler (in conformity to law); and the judicial authority (to award to each what is his in accordance with the law) in the person of the judge... These are like the three propositions in a practical syllogism: the major premise, which contains the law of that will; the minor premise, which contains the command to behave in accordance with the law, that is the principle of subsumption under the law, and the conclusion, which contains the verdict (sentence), what is laid down as right in the case at hand. (MM 6:313)

The idea of the public authority, in other words, is seen as divided into the three legal-political functions it has, namely the general specification (the sovereign, legislative authority), the particular specification or application (the judiciary authority), and the enforcement (the executive authority) of the law. In addition, since the general specification of the law has to occur prior to the specific specification, or application of this law to particular cases and the consequent enforcement of the verdict, the legislative function is the fundamental one and where the sovereign authority lies. Also, it is important to note that the public authority only acts through law, meaning that all exercises of public authority must be lawful. It is furthermore important for Kant that these three components can be thought of as "persons" in that they are inherently normative ideas enabled by our ability to be morally responsible for our actions and that these three persons can be seen as "distinct authorities ... by which a state has its autonomy, that is, by which it forms and preserves itself in accordance with laws of freedom." (MM 6:318) That is to say, the three authorities must be legally (institutionally and functionally) distinguished from, yet seen as complementing each other in any minimally rightful state. Such a public tripartite legal-political authority is necessary for the citizens' interactions to be subjected to (universal, public) law only and not to one another's (private) choices, and so for the state to obtain its autonomy (be self-determining in accordance with law). ${ }^{10}$

Complementing this specification of the idea of the state, Kant also adds a clarification of the idea of the citizen. Because this is a complicated piece of text, let me quote Kant at length here:

The members of such a society who are united for giving law... are called citizens of a state... In terms of rights, the attributes of a citizen, inseparable from his essence (as a citizen), are: lawful freedom, the attribute of obeying no other law than that to which he has given his consent; civil equality, that of not recognizing among the people any superior with the moral capacity to bind him as a matter of right in a way that he could not in turn bind the other; and third, the attribute of civil independence, of owning his existence and preservation to his own rights and powers as a member of the commonwealth, not to the choice of another among the people... The only qualification for being a citizen is being fit to vote. But being fit to vote presupposes the independence of someone who, as one of the people, wants to be not just a part of the commonwealth but also a member of it, that is, a part of the commonwealth acting from his own choice in community with others. This quality of being independent, however, requires a distinction between active and passive citizens, though the concept of a passive citizen seems to contradict the concept of a citizen as such. The following examples can serve to remove this difficulty: an apprentice in the service of a merchant or artisan; a domestic servant (as distinguished for a civil servant); a minor... all women ... All these people lack civil personality... This dependence [these people have] upon the will of others and this inequality is, however, in no way opposed their freedom and equality as human beings, who together make up a people; on the contrary, it is only in conformity with the conditions of freedom and equality that this people can become a state and enter into a civil constitution. But not all persons qualify with equal right to vote within this constitution, that is, to be citizens and not mere associates in the state. For from their being able to demand that 
all others treat them in accordance with the laws of nature freedom and equality as passive parts of the state, it does not follow that they also have the right to manage the state itself as active members of it, the right to organize it or to cooperate for introducing certain laws. It follows only that, whatever sort of positive laws the citizens might vote for, these laws must still not be contrary to the natural laws of freedom and of the equality of everyone in the people corresponding to this freedom, namely that anyone can work [one's ${ }^{11}$ way up from this passive condition to an active one. (6: 314f)

The general idea of the citizen comprises, as we can see, the ideas of: a) lawful freedom, namely to be subject only to laws to which one has given one's consent (through voting); b) civil equality, meaning to be treated by the laws of right as an equal subject with everyone else; and, finally, c) civil independence, that is, being able to secure one's own existence and preservation merely by acting within the rights and powers everyone necessarily has as a member of the commonwealth, and hence, importantly, having this possibility not subjected to the choice of anyone else in the people.

Notice, first, that Kant here is quite careful to state that although freedom gives one a right to vote on the laws one is subjected to, one does not thereby have a right to decide (vote on) whether or not all citizens get rights or get sufficient legal protection to secure their basic existence and preservation. Moreover, the second condition, equality, secures each and all citizens the same basic (private and public) rights, whereas the third condition, independence, secures each and all citizens the right to legal protection of their basic rights, including legal access to basic means. What one obtains the right to vote on through one's right to freedom is not, therefore, a right to vote to set aside the conditions of equality and independence-this no one can view themselves as authorized to do-but to vote on the specification of the laws by means of which one secures all citizens' basic rights (taking part in the process of the specification or positing of private and public laws; exercising sovereign, legislative authority). Still, Kant emphasizes, one must allow for a distinction with regard to the first condition-freedom-since not everyone is able to vote as they lack the independence this requires. Of course, the obvious and non-controversial example here is children: children cannot as yet be morally responsible (lack the reasoning resources such independence requires), which is why they cannot be morally responsible for (vote on) the laws by means of which we enable rightful interactions between us, including interactions involving children (such as relevant parts of family law). (I return to the complicated categories below; women and servants.) And yet also they (those incapable of voting) are members of the people, which is why we need a distinction between "active" and "passive" citizens, where this distinction tracks whether or not citizens are deemed capable of taking active part in the legal-political process concerning legislation (voting). Moreover, Kant emphasizes that also passive citizens must be facing a totality of institutions where their possibility of working themselves into a condition of true independence (active citizenship with voting rights) is neither made illegal (those who can vote on laws cannot posit a law, according to which it is illegal for all citizens to work themselves into an active condition) nor made subject to another (private) citizen's choice.

After having outlined these ideas of the state and of the citizen-and I return to them in more detail below-Kant moves on to describe various other aspects of the public authority, or the liberal legal-political institutional framework. It is especially with regard to these sections I believe that Kant, as mentioned above, views his account of public right as somewhat incomplete and less worked out than one might ultimately expect and want in a theory of justice. Although incomplete, Kant does provide some help as we try to complete the theory, however. Most importantly, perhaps, is Kant's suggestion that we can draw a distinction between five different public right elements constitutive of the legal-political institutional framework of the just state. He gives each aspect its own quick discussion in short sections entitled, simply, sections "A" through "E." In short, in section A we find a brief discussion of what he calls the three forms of state (autocracy, aristocracy, and democracy) as well as an argument for why we cannot have 
a right to revolution (MM 6: 318-23); in section B, we find an argument for why the public authority cannot own anything as private property as well as some arguments concerning the state's right to legally regulate systems such as those concerning land, the economy, and the financial system (MM 6: 323-25); in section $\mathrm{C}$ we find some arguments concerning the state's role in relation to issues of poverty and religious institutions (MM 6: 325-28); in section D, we find some arguments concerning public offices and dignities (MM 6: 328-30); and, finally, in section E, we find a discussion of punishment and the granting of clemency (MM 6: 331-37).

As with Kant's account of private right, his account of domestic public right has given rise to a host of interpretive disagreements. ${ }^{12}$ In addition to divergence of interpretation regarding each of the public right principles or ideas, there is significant discussion concerning both how to understand the category of public right as a whole as distinct from and related to the category of private right as well as how this (ideal) account is related to (non-ideal) considerations concerning national, historical particularity and problems issuing from our warped wood (our more nasty sides). Regarding the first question (how the category of public right relates to the category of private right), prudential accounts proceed in a libertarian manner and argue for something like a minimal state (since the state's justification is simply that it does better what individuals in principle can do, but are so terribly bad at doing on their own in the state of nature); or they take decisive steps away from such libertarian parameters and instead appeal to various kinds of needs or welfare considerations so as to justify a more socio-economically expansive Kantian state; or they proceed in realist, legal positivist directions where the state can and will do whatever it takes so as to bring about a stable, rule-governed society; or they proceed in more democratic legal positivist directions by arguing that what matters is that the rules have sufficient, actual support in the people. In contrast, the non-prudential (ideal) interpretations disagree not only with these approaches but also among themselves on the question of whether or not Kant thinks that because the state must establish the monopoly on coercion, it must also establish a new set of systemic rights and duties for the citizens beyond those needed to establish the tripartite public authority and the basic public administrative institutional framework. Those scholars who answer "yes" on this question typically proceed to argue that various kinds of socio-economic rights, such as rights to poverty relief or unemployment benefits should be understood as systemic rights, meaning public right-claims citizens have on their own public institutions (only) and not with regard to each other as private citizens. Regarding the second question concerning how Kant's ideal theory relates to non-ideal considerations of various kinds, such as historical particularity and reform, there is currently a lot less discussion in the literature, and, as mentioned in the introduction, this is the main area with regard to which the present paper aims to make a new contribution.

Before giving some reasons why I believe these non-ideal issues are important to attend to, let me locate my approach to Kant's theory of right within this interpretive web-an approach that may be labeled a liberal republican interpretation-as well as indicate why I believe that there is nothing in my account (the arguments themselves, at least) that cannot be accepted by any liberal account (whether of a libertarian, legal-positivist, Rawlsian etc. kind) even if they may want to add other arguments so as to yield different conclusions regarding specific issues. On the one hand, I defend (elsewhere) an interpretation along the ideal, more complex lines regarding private right. More specifically, I argue (with and for Kant) that there are both ideal problems of indeterminacy regarding the general specification of the private right principles and regarding the application in particular cases as well as ideal problems of assurance that only the public authority can solve, namely in virtue of being the (only) means through which we can provide (general and specific) determinations of the general principles of right that are rightfully enforceable. Each problem (which is conceived of as impossible to solve even by persons with perfectly virtuous intentions in the state of nature) is then linked to the three-fold nature of the public authority (respectively): the sovereign 
legislative (general specification, or positing of laws) authority, the judiciary (particular specification, or application of laws), and the executive authority (assurance, or actual upholding of laws). The public authority is therefore not yet another private person, but a public person or institution through which we enable rightful interaction among ourselves, including rightful coercion. This is why it is only through establishing the public authority that we can solve the problems that in principle are unsolvable in the state of nature, that is, the problems of indeterminacy (the general and particular specification, or the positing and application of law) as well as the problem of assurance (upholding the law by force as a moral, or justifiable fact) in a way reconcilable with respecting one another's innate right to freedom. The establishment of the public authority makes possible enforceable rights (without wrongdoing), or conclusive rights. ${ }^{13}$

My interpretive approach also follows the more complex, ideal liberal lines of interpretation concerning public right. ${ }^{14}$ Hence, on my interpretation, part of what is distinctive about Kant's approach to justice is that his account of public right includes separate arguments concerning systemic right. It is in virtue of this feature that his position can make good sense of various types of rights tracking socio-economic distributive issues, systemic issues that otherwise are hard to make sense of in liberal theory since they are difficult to explain in terms of rights individuals have in relation to each other as private individuals. For example, Kant's argument for why the state has a right and duty to guarantee unconditional poverty relief for all its citizens is that once the state assumes a monopoly on coercion (which it must), it must reconcile this monopoly on coercion with each citizen's innate right to freedom. The innate right to freedom is a right to independence from having the possibility of freedom subjected to another person's arbitrary choices and instead subjected only to universal law, and the only way to do this is by securing unconditional, legal access to means for each citizen. Indeed, as we saw above, this is also exactly how Kant explains the idea of citizens' independence above, namely as centrally involving the idea "of owning his existence and preservation to his own rights and powers as a member of the commonwealth, not to the choice of another among the people." (MM 6: 314) $)^{15}$

Finally on these interpretive points, it seems to me that these (private and public right) arguments of Kant's can be accepted by any liberal, including rightwing libertarian positions, even if some of them may want to add other arguments. The account and arguments below concerning Kant's conception of self-governance and especially the related discussion of public representation are, I believe, also of this sort: they can be accepted by any liberal account, that is, any account compatible with the ultimate reference of justification of coercion in a legal-political system being each person's innate right to freedom understood in terms of private independence and equal subjection to universal laws. ${ }^{16}$ And they may be tempted to do this because the resulting account provides at least an interesting, contemporary way of giving due consideration also to various non-ideal considerations, such as our national-historical particularity and systemic injustice. In addition, the account also enables us to say something more about which kinds of institutions we must strive to establish so as to ensure that our legal-political frameworks not only are reconcilable with the basic liberal idea of the state as enabling rightful interaction between its citizens as free, equal, and independent, but as how a people so committed may seek to reform their institutions so as to enable conditions in which everyone can flourish through their own efforts. The fact that Kant does not identify democracy as a form of state that is constitutive of all minimally just states is, I will also suggest, a strength rather than a weakness of his account.

\section{PART II: SELF-GOVERNANCE AND REFORM}

One reason why it's hard to identify the outlines of Kant's idea of self-governance is simply that nowhere does he provide us with terribly much help to understand it. In fact, as mentioned above, Kant judged his most mature published account of public right (in the Doctrine of Right) as incomplete in this regard. 
In addition, in the relevant segments of his text it is often less than obvious if Kant views his conclusions as holding regardless of whether or not we include in our reflections non-ideal assumptions concerning human nature, including concerning our social ${ }^{17}$ and crooked (vicious) ${ }^{18}$ aspects. Hence, sometimes Kant seems to argue in ways that are clearly intended only to appeal to considerations of reciprocal external freedom and to people who really do or only want to interact in ways consistent with respecting each others' innate right to freedom. Other times, however, Kant somewhat surprisingly appeals to human nature, including the historical, particular condition a state or people finds itself in, before proceeding to make (sometimes, seemingly very provocative) claims about how we should think about interaction given such conditions. For example, Kant (infamously) seems to say things like: even if we judge the conditions in which we find ourselves horribly unjust, we still must obey the public authority, and that some people (richer men) are, as the saying goes, "more equal than others" (as mentioned above: the poor, women) and this is why only the former (richer men) get to vote. Hence, in these kinds of passages it looks as if Kant contradicts all his ideal talk about equal rights to freedom understood in terms of independence; after all, here he seems to say that, somehow, we can be (and some are) morally obliged to accept being treated as unfree, as unequals, and as privately dependent on others in our exercise of freedom. Also confusing to any Kant interpretation is the fact that it is not easy to clarify exactly what form of state Kant thinks can issue political obligations - monarchies, aristocracies, democracies only, or?

A main aim in the section below is to address these interpretive issues. To do this, I first (section 2.1 "How Freedom Accommodates Human Nature in Kant's Doctrine of Right") defend the interpretive assumption that Kant remains firmly committed to the idea that although ideal theories of justice as freedom can and sometimes should make space for non-ideal considerations concerning our human nature (including historical particularity and our tendency to do evil things), they cannot let such contingent (non-ideal) considerations set the framework for non-contingent (ideal) considerations. I finish this section by suggesting that according to Kant, the idea of the just state (the republic) is compatible with all three forms of state-autocracies (monarchies), aristocracies, and democracies-and not only one of them. With these two interpretive assumptions at hand, I continue (in section 2.2 "Reforming Minimally Just States") to argue that we can now make quite good sense of both an idea of a minimally just state within Kant's framework and his idea of reforming such a minimally just state into a more flourishing, ideal version of it. I argue that Kant can be seen as defending a coherent position without giving up any of the (often presumed incompatible) elements he proposes in various works, such as: that the three possible forms of state can come in four different versions (anarchy, despotism, barbarism, and the republic) depending on how force, freedom, and law are unified in a particular state; that only the republic combines force and freedom in such a way that the enforced law can successfully establish rightful conditions; that a just states can distinguish between active and passive citizenship; and, finally, the idea that citizens govern themselves through public reason in well-functioning, or flourishing just states. The resulting position is, I propose, also a promising way of seeing how ideal and non-ideal considerations can work together when analyzing particular issues concerning the way in which public, representative self-governance is constitutive of rightful interaction in a flourishing republic, namely a state where "law itself rules and depends on no particular person... [where there is] a system representing the people, in order to protect its rights in its name, by all the citizens united and acting through their delegates (deputies)." (MM 6: 341) ${ }^{19}$

\subsection{How Freedom Accommodates Human Nature in Kant's Doctrine of Right}

Before going into specifics regarding how Kant envisions public self-governance in just states, let me provide some reasons to read Kant as maintaining that the idea of the just state itself is comprised of ideas that do not appeal to our human nature (non-ideal considerations), that is, neither to concerns regarding 
our natural sociability (and particular histories) nor to the empirically universal ${ }^{20}$ fact that we act badly at times. Instead, I will suggest, Kant views it as essential for a theory of justice to make space for such non-ideal considerations while remaining firmly committed to the idea that the non-ideal should not set the framework for the ideal, but the other way around. And for good reasons: freedom cannot be ideally, coercively limited by anything but considerations of freedom itself-any other limits must be considered fundamentally contingent, and hence also correctible, over time, namely as conditions of freedom become more firmly established in a state.

Time and time again in the Doctrine of Right, Kant emphasizes that his principles of right (justice) are a priori principles and that the core ideas of right, such as those of the state and of a citizen, are pure ideas of reason (MM 6: 313). Similarly, Kant makes it clear at the beginning of his discussion of public right that

however well disposed and ... [right-loving ${ }^{21}$ men might be, it still lies a priori in the rational idea of such a condition (one that is not rightful) that before a public lawful condition is established individual human beings, peoples, and states can never be secure against violence from one another, since each has its own right to do what seems right and good to it and not to be dependent upon another's opinion about this. (MM 6:312)

Although there is much we may disagree about in this passage, what seems clear is that Kant's argument is supposed to go through even without appeals to our human nature, meaning our actually being well disposed and deeply devoted to what is right ("right-loving"). This is not to say that Kant does not consider concerns and problems of justice that are grounded in our human nature (again, our natural sociability and our propensities to do evil) as relevant to justice. It is only to say that Kant's account of the just state- the arguments comprising his ideal critical standard—should succeed in yielding a coherent, critical perspective of freedom without such non-ideal considerations. ${ }^{22}$

Attributing to Kant the view that non-ideal concerns (considerations of human nature) should not set the framework within which ideal concerns (those based on considerations of freedom) are given space, but the other way around, is not an interpretive stretch. In my view Kant explicitly makes exactly this point in his introduction to The Metaphysics of Morals, where he says that:

... moral anthropology ... deal[s] ... with the subjective conditions in human nature that hinder people or help them in fulfilling the laws of a metaphysics of morals. ... It cannot be dispensed with, but it must not precede a metaphysics of morals or be mixed with it; for one would then run the risk of bringing forth false or at least indulgent moral laws, which would misrepresent as unattainable what has only not been attained just because the law has not been seen and presented in its purity (in which its strength consists) or because spurious or impure incentives were used for what is itself in conformity with duty and good. This would leave no certain moral principles, either to guide judgment or to discipline the mind in observance of duty, the precepts of which must be given a priori by pure reason alone. (MM 6:217)

What we see here in this quote from the introduction to The Metaphysics of Morals, then, is that Kant is most concerned with not giving features concerning our human nature (both our natural sociality and our propensity to evil) a role where they get to determine which arguments concerning right that are ideally justifiable to beings like us, beings capable of freedom and moral responsibility. Freedom can only be limited in the name of freedom - and so is restricted to considerations of reciprocal freedom — and any arguments grounded in human nature (good and bad) are fundamentally contingent, and so cannot set the framework for freedom (free choices). Arguments concerning human nature are non-ideal or conditional (in that they presuppose certain ends) and so cannot set the framework for the ideal or the unconditional (what we can all accept as justifiable merely in virtue of being committed to respect one another's right to set ends of our own). ${ }^{23}$ 
This general approach gains further interpretive support in Kant's anthropological and historical works where Kant talks about related issues; also in these works there is little doubt that Kant thinks of the realization of just societies as a slow endeavor and not as something that is easy to accomplish or as something that we will necessarily succeed in doing. For example, in the Anthropology, Kant spends a significant amount of time emphasizing the slowness of developing the human predispositions to good to its fullest, including because it is both something we must do together and something that requires education (A 7:322-30). Moreover, it follows from what Kant says there that if he makes claims concerning history or moral anthropology that are mistaken (and so wrongly makes space for them in his ideal theory of justice), then this can and should be corrected. Kant is not only worried that others may make mistakes, in other words, but also that he might be making mistakes by "misrepresent[ing] as unattainable what has only not been attained just because the law has not been seen and presented in its purity." (MM 6:217) And this problem of mistakes (bad judgment) is one main reason why it is so important that freedom (the unconditioned) is what sets the framework of justice, and not the contingent facts (including historical and anthropological ones) that such an ideal theory of freedom must make space for.

Moral anthropology deals with various aspects of us that concern our human nature. As mentioned, in the Religion Kant views human nature as comprising a threefold "original predisposition to good in human nature," namely as comprising one predisposition to animality, one to humanity, and one to personality. (R 6: 26ff, cf. CPrR 5: 73) ${ }^{24}$ This is not the place to go into too much detail about this, but let me say a few words about this point more generally before suggesting one way to understand it as informing some of Kant's comments about historical development and philosophical anthropology and peoples in his legal-political writings. To start, Kant's basic suggestion is that issues concerning our natural drives to self-preservation, sex, and affectionate social unions with others are to be understood in terms of our predisposition to animality; our susceptibility to consider and being considered as valuable by others through the predisposition to humanity; and finally, our susceptibility to recognize the need reflectively to consider the morality of our actions through the predisposition to personality. In addition, the extent to which reason is required to realize each of these predispositions differs: the first (to animality) doesn't require reason as such (although we do also these things consciously); the second (to humanity) involves comparative uses of reason; whereas the final one (to personality) inherently involves full-blown (self-reflective) uses of reason. ${ }^{25}$

It is because of the third predisposition, to personality, Kant furthermore suggests, that we are able to act in morally responsible ways, namely by using self-reflective powers of reason to act rightfully and/or virtuously, including by correcting bad realizations of the first two predispositions. More specifically, when we do so correct from the point of view of right (ensure that we act rightfully), Kant argues, we evaluate whether or not our actions are consistent with respecting each person's innate right to freedom (and corresponding private and public rights) as described in his ideal legal-political writings, whereas when we correct from the point of view of ethics (virtue), we consider whether or not the maxims of our actions can be universalized as described in his ideal writings on ethics and virtue-and act as motivated by this reflection. Finally, it seems clear that developmentally, Kant's proposal is that although we do all things consciously, we first succeed in starting to master the animalistic capacity, then we start mastering the capacity for humanity, whereas the reflective capacity enabling personality is the slowest one we master. It takes quite a long time, in other words, for us to develop the ability to be morally responsible, whereas the abilities to seek nutrition and to love someone affectively (as enabled by the predisposition to animality) and to have a sense of oneself through other's affirmation of us as who we are (as enabled by the predisposition to humanity) are more easily realized (developmentally). 
If we view this account as informing Kant's conceptions of peoples, nations, and national development, it seems that we can utilize the accounts of the predispositions to animality and humanity—and in particular as it relates to our sociality-to explain how we naturally and affectionately love the society (or people) and/or country (or nation) into which we happen to be born and how we want to develop its culture. This is because on this kind of position, our sociality is enabled by our capacities for animality and humanity, or the unreflective and comparative, emotional orientations linked to our basic sense of being at home in the world and to others as being oriented towards us as mattering. Hence, this capability for animality is linked to our sense of some particular persons, such as our families and friends, being ours, but also how the society in which we are brought up, assuming this is an uncomplicated upbringing, is affectionately related to as our society or, when larger, people or nation. That we are so oriented, as such, is not a problem. This is just the kind of embodied, social beings we are and it is consistent with what we upon reflection can justify. After all, that I affectionately only love my loved ones (my spouse, my children, my friends) is not inconsistent with morally loving everyone - treating all humans with respect and as possessing dignityjust like my loving my people or country is consistent with my utmost respect (moral love) for all other countries and all peoples as well. Hence, loving one's persons or one's people or country affectionately is something we can affirm upon reflection; there is nothing wrong with be so emotionally oriented, as such; in fact, quite the opposite. ${ }^{26}$ As long as such national affection and related culture (and cultural differences) is developed within a moral framework, including legal frameworks based on respecting each citizen's innate right to freedom and respect for other states' autonomy as well, there is nothing wrong with such national affections and national-cultural affections and identities. Rather, given human moral psychology and corresponding philosophical anthropology, this is as it is for us. The mistake is only to view, as we will see in more detail below, these personal, social, and cultural affections as the sources of morality-of what can be justified to all, and so to be done in the name of freedom - for that they are not. Finally, on this point, it also seems relatively unproblematic to say that it takes human societies a long time too to develop from being focused on basic survival and a sense of safety ("animality"), to being able to cultivate a flourishing culture ("humanity"), to being able to enable and secure conditions of freedom for all, including through legal-political institutions ("personality") (A 7:322-5).

Why, then, do we or are we so extremely likely to get this wrong, including by easily being profoundly confused about some or all of this, at least sometimes? Answering this question brings us to the other aspect of Kant's non-ideal account, namely the one that deals with our propensity to evil, which is also addressed in his Religion. Kant here explains that our human nature includes a propensity to evil, meaning that our natures are extremely liable to being corrupted due to problems resulting from our ability to choose (also unwisely). The problem, then, is that our sensuous receptivity enabled by the first two predispositions (to animalistic pleasures and feelings of interpersonal power) in combination with our capacity to choose gives rise to temptations to do something simply because it feels very pleasant or empowering (especially in the moment); a (perverted) sense of freedom. Hence, Kant argues, our ability to choose in combination with our sensuous receptivity give rise to problems from "weakness of will" (lapses where we yield to the temptation of pleasure or senses of empowerment in the moment) to "impure incentives" (doing the right thing from the wrong incentive) to "perverted hearts" (structuring our lives in self-and other-destructive ways). The problems issuing from our propensity to evil obviously remains a constant threat for any moral, and so also any justice seeking, project. Indeed, as Kant explains in the Anthropology, our propensity to evil remains a constant source of threat also for civil society:

In a civil constitution, which is the highest degree of artificial improvement of the human species' good predisposition to the final end of its destiny, animality still manifests itself earlier and, at bottom, more powerfully than pure humanity.... The human being's self-will is always ready to break out in aversion toward his neighbor, and he always presses his claim to unconditional freedom; freedom not merely to be independent of others, but even to be master 
over other beings who by nature are equal to him... This is because nature within the human being strives to lead him from culture to morality, and not (as reason prescribes) beginning with morality and its law, to lead him to a culture designed to be appropriate to morality. This inevitably establishes a perverted, inappropriate tendency: for example, when religious instruction, which necessarily should be a moral culture, begins with historical culture, which is merely the culture of memory, and tries in vain to deduce morality from it. (A 7:327-8)

Of course, Kant's example here is how the combination of the early development of our existentially powerful capacities to animality and humanity and the vices that our capacity to choose (and so our wanting to feel absolutely free or powerful) are internally linked to the common fact that religious instruction understands itself as beginning with "historical culture" rather than with "moral culture," or what can be justified to morally responsible beings (persons). ${ }^{27}$ That is to say, religious instruction (as an actual practice) often understands and presents itself as having its justification in the culture of memory (historical culture) in which it is situated rather than in virtue of being justifiable to such cultural (social beings) who are also capable of moral responsibility (true freedom). This mistaken approach—doing religion in such a way-is terribly tempting to us because of the way in which doing it this way feeds our propensity to evil, namely a sense of importance (being part of some grand, historical enterprise much better than all the rest) or of being inherently better than others rather than interact with everyone as equals (in ways respectful of our inherited, cultural differences). Of course, the same can be said of nations: a problem with some forms of bad nationalism is that it purports to justify the claim that one's nation is better than others and that the inherited culture (whatever it is taken to be) sets the framework for freedom rather than the other way around. And then, in vain, those political leaders who participate in public life in this way, try to argue that there are these special Norwegian, French, British, American, etc. (or what is also common, "Western") values that somehow set the framework for permissible exercises of freedom in one's own particular nation, rather than maintaining what is justifiable, namely that our shared, capacity for freedom (moral responsibility) is what always must set the framework within which any claims to accommodation of cultural difference must (justifiably) be made. ${ }^{28}$

\subsection{Reforming Minimally Just States}

In order to understand what Kant means by saying that we must reform our inherited, non-ideal states into better realizations of them, it is useful to clarify what, for Kant, a state is at all (whether imperfect or perfect) when it issues political obligations. To do this, as suggested above, it seems fruitful to draw a distinction between a minimally just state (imperfect realization of the idea of the state) and a more flourishing state (the civil condition more fully realized). And to do this, in turn, a good starting point is Kant's concepts of anarchy, despotism, barbarism, and the republic in the Anthropology, since with this analysis at hand, we can understand more clearly the related arguments presented in the related domestic public right section of the Doctrine of Right. In short, my suggestion below is that although anarchy need not be a condition of injustice (since it can be merely a condition devoid of justice), only the republic is the civil condition (can issue political obligations) since only it contains the basic legal-political institutional framework needed for reform to do the work necessary to realize the civil condition more fully. This account also helps us understand why Kant suggests that when we succeed in reforming our states, we improve the functioning of the legal-political institutional framework in certain ways. He also gives us good reasons to be weary of any appeals to human nature to justify inequalities regarding actual rights, namely so as to ensure we're not misrepresenting as unattainable or even wrong what only (at best) our own prejudices, insecurities, and vulnerabilities have kept us blind to. This is why, as we saw above, Kant maintains that the account as a whole must always have a structure, according to which human freedom cannot be justly limited by human nature. It is also why, as mentioned above, we should look at the areas of public right labelled sections A through E in the Doctrine of Right for clues regarding which institutional structures we should pay special attention to as we seek to reform our imperfect states. ${ }^{29}$ 


\subsubsection{The three forms of the state}

Turning first to the issue of the ideal forms of state, Kant thinks that there isn't only one possible form, but three. Hence, it is mistaken to think that his analysis of the minimally just state starts on the assumption that it must be a democracy. Kant is explicit in the Doctrine of Right that the idea of the tripartite public authority (legislative, judicial, executive authority) as representing the general, united will of the people can be understood as held by or entrusted to one person (autocracy: one active citizen), by a few persons (aristocracy: a few active citizens), or by many (democracy: many active citizens) (MM 6: 338f). ${ }^{30}$ In the Anthropology Kant argues similarly. Here he makes this point in connection with arguing that force, freedom, and law maybe combined in four different ways, yielding anarchy, barbarism, despotism, and the republic. Having clarified this, Kant proceeds by pointing out that "only the last combination [republic] deserves to be called a true civil constitution; by which, however, one does not have in view one of the three forms of state (democracy), but understands by republic only a state as such." (A 7:331) I will return to this passage momentarily, but for now notice that each of the three forms of state can be realized as the civil condition — as a republic — and hence the minimally just state (the one that can issue political obligations) does not necessarily come in the democratic form.

Correspondingly, in the Doctrine of Right Kant ends his discussion of domestic public right by emphasizing the kind of patience we need to have in our justice seeking projects, namely to reform our (typically inherited) imperfectly just states - whichever form they have-into more flourishing republics, where the "pure idea" of the state is sought realized through some good ideals of it. (MM 6: 340f) A hard question for any interpretation, therefore, is to figure out what Kant means by saying that each of the different forms of state can be realized as republics, and how actually to go about doing this. My suggestion below is that states with any of these forms of state are republics because they can be reformed into better and better means through which a people realize justice together through public self-governance. The reform consists mostly in making the public legal-political structure increasingly representative in its operations, including by how we, over time, rid the public systems of hereditary, non-merit based privileges and also make it actually possible for everyone to work their way into taking active part in the public life of the state through facilitating social mobility.

\subsubsection{The four possible combinations of force, freedom, and law: anarchy, despotism, barbarism, and republic}

Kant's idea of the imperfectly, yet minimally just states is easiest to get a handle on by utilizing his comments in the Anthropology regarding the four different ways in which freedom, law, and force can be combined. Since this is an important piece of text, let me start by quoting Kant somewhat extensively on this point:

Freedom and law (by which freedom is limited) are the main pivots around which civil legislation turns. - But in order for law to be effective and not an empty recommendation, a middle term must be added; namely, force, which, when connected with freedom, secures success for these principles. Now we can conceive of four combinations of force with freedom and law:

\footnotetext{
A.Law and freedom without force (anarchy).

B. Law and force without freedom (despotism).

C. Force without freedom and law (barbarism).

D. Force with freedom and law (republic).
} 
One sees that only the last combination deserves to be called a true civil constitution; by which, however, one does not have in view one of the three forms of state (democracy), but understands by republic only a state as such. (A 7: 330f)

The state of nature, as noted above, does not have to be a condition of injustice, but it will be a condition that is at best devoid of justice. It is clearly this situation Kant appeals to with his concept of "anarchy" here: We can imagine a situation in which everyone happens to agree on the general (positing) and particular (application) specification of the principles of right, and consequently they never experience any (reasonable or unreasonable) disagreement regarding how their exercises of freedom should be restricted when they interact. In such a situation, there would naturally also be no wrongful uses of coercion; after all, there would never be any use of coercion whatsoever. This would be the best possible anarchical situation, and so one in which we have not enabled justice (since rightful uses of coercion are impossible in this condition) but also one in which there is also no injustice; it is simply a condition "devoid of justice," as Kant argues in the Doctrine of Right, since if there arises any (reasonable or unreasonable) disputes concerning right "there would be no judge competent to render a verdict having rightful force." (MM 6: 312) The only condition worse than the state of nature so conceived (anarchy) is one in which there is much use of force, but no freedom and no law securing rights for all citizens (barbarism). In such a barbaric condition, the use of force is not restricted by considerations of freedom and law; there is only brute force (violence), which is why Kant calls it a barbaric condition. Both of these conditions are therefore not even minimally just; one ("anarchy") is (necessarily) devoid of justice, the other one ("barbarism") is (necessarily) only unjust.

The two other possible conditions are, respectively, "despotism" and the "republic" (civil condition), according to Kant. Both combine force with law, but despotism does not combine force with freedom, and so cannot succeed in realizing both freedom and law, which are the "pivots around which civil legislation turns." Despotism, then, is a condition characterized by law and force, but there is no freedom because there is no representation even in the most basic sense of the word since there are neither any active citizens in this condition nor is the basic right to freedom secured. On the one hand, therefore, a main problem is that the those wielding power take themselves as holding this power as private persons rather than as public officials representing the people who are entrusted to act on behalf of the people so as to enable rightful, lawful interactions between each other as free, equal, and independent. There is, in other words, no public authority in a despotic condition, only private authority. In despotic societies, some person(s) holds power in a way that it is fundamentally not representative (of the people and their rights) in nature, and hence there is no path (as yet) internal to the principles of the legal-political institutional system itself, whereby conclusively rightful relations is or can be secured. More specifically, in a despotic autocracy only one person is, in a despotic aristocracy a few persons, and in a despotic democracy a subset of the citizens view themselves as having and actually have subjected all others to her or his private choice (to laws of her/his choosing). This is why, in despotic societies there is no freedom, but force and law only, since there is only private power: one or more private individuals de facto subject everyone else to their private choices regarding which laws that are to be followed rather than laws constitutive of enabling rightful interactions among the subjects as free, equal, and independent. That is to say, in such a society, there are laws in the sense of a rule-governed legal-political institutional framework-there is security in this sense-but not one that is based on the protection of all citizens as free and equal, and so in terms of the citizens' basic right to freedom with its corresponding innate, private, and public rights. Despotism is therefore not a civil condition, since only provisional justice is possible within it - which occurs each time there is agreement and no use of coercion or when the laws in effect can be seen as instantiations of the general principles of innate, private, and public right (like with anarchy) — and hence such a condition cannot issue political obligations. Because there is force used in this (despotic) condition, however, it is 
necessarily a condition of injustice. Still, because there is rule-governed stability in this society and since one does not have a right to use violence against others, it is often prudent and wise to work within it to strive towards the establishment of civil society.

The republic, in contrast, is a condition where force is combined with freedom and law such that force "secures success for these principles" (of freedom and law), which is why only the republic involves the establishment of a public authority. A key here is that the persons wielding power in this condition are not (by law) anything but representatives of the people, namely by being fulfilling their role as genuinely public persons. The highest public authority in the republic is functionally and institutionally tripartite, and, relatedly, the one or ones who are legally recognized as entitled to vote on the laws is the active citizen(s). Correspondingly, of course, in such a state, those with voting powers simply specify the innate, private, and public laws of freedom that regulate interaction and all public officials are required to strive towards analysing public matters and wield public authority in an inherently public way, namely in line with the public policies governing their public offices as well as with ideas of the citizens as free, equal, and independent. In the republic public officials only take themselves to be acting and are only legally authorized to act on behalf of each and all citizens, and in line with the relevant laws and policies regarding how this is to be done. The public officials are not legally entitled to view their offices of authority as private spheres of power and choices; when the public offices are treated in this (private) way, they are viewed (including legally) as being corrupted. The republic is the only legal-political condition, in which the citizens enjoy basic rights of freedom (as force is delineated by means of these rights) and so the only one compatible with reform actually leading to a condition where the people govern themselves through their public legal-political institutions. That is to say, once reform has succeeded, in such a state all morally responsible citizens can work themselves into a condition where they actively can participate in the public institutional framework, including by partaking in informed ways in public reason generally and by holding any of the public offices (become active citizens); this is where the people rule themselves through public law and this possibility does not depend on any particular person.

If the above analysis is correct, then as soon as the legal-political framework of the minimally just state is in place, then political obligations exist and the task of reform starts. And to sum up, the minimally just state is in place when the public authority itself is established as a tripartite, public authority that represents the people in virtue of securing their basic rights to freedom (their innate, private, and public rights). As emphasized above, this (minimal condition) is compatible with legislative authority being held by only one person (a monarch as the only active citizen), by only a few (an aristocracy delimiting the small group of active citizens), or by many (democracy where many act as active citizens); the only crucial point is that the three elements of the public authority must be institutionally distinct, must be representational in character, and aim simply ruling through specification, application, and enforcement of each citizen's basic rights (to freedom). In none of these republics, are those entrusted with public authority legally recognized as ruling the people by their private choices. Rather, the one, the few, or the many recognized as active citizen(s) in virtue of being able to vote on the specification of the laws (legislative authority) and all those who are holding the other two highest public offices (judiciary and executive authorities) are viewed as legally entrusted to represent the people by reasoning in specific ways as they apply or enforce the posited laws of freedom regulating the people's interactions. Moreover, the basic rights that are specified in a minimally just state include each citizen's innate, inalienable right to freedom, which includes legally guaranteed a right to each category of innate right (such as right to one's body and to freedom of speech), of private right (private property, contract, and status right), and of public rights concerning the systems upon which her or his exercise of freedom is made dependent by the establishment of the state's monopoly on coercion (such as movement across land, unconditional poverty relief, access to trade in an economy and with legal tender, recognized as equal subject to the law etc. ${ }^{31}$ ). 
It seems important to reiterate that that in the minimally just state it is possible that pretty much everyone are what Kant calls "passive" citizens, since they cannot vote on the legislation or cannot take direct part in the running of the public authority - and because this is where the power to determine exactly how to limit freedom in the name of freedom, they are passive subjects rather than active members of the state. Let me explain this from a somewhat different direction: above, we saw that Kant defines a citizen in terms of freedom, equality, and independence, and that he distinguishes between active and passive citizens by virtue of whether or not they are given full freedom, which ultimately is to have a right to vote on the actual laws governing their interactions with one another. The reason for this two-fold distinction, Kant argues, is that being an active citizen requires that one is "fit to vote" (6:314) although, as we have seen, it cannot be illegal for anyone to work themselves into active citizenship. At the same time, Kant maintains, the sovereign authority may as a matter of legal fact simply not be open up for anyone other than those who already have sovereign power or be legally recognized as having the right to attain it: sovereign (legislative) and/or other public authority may be restricted to only one person and its descendants (as in a hereditary monarchy), or a few families (hereditary aristocracy), or some group of citizens (like only sufficiently wealthy male citizens), whereas all the rest are obliged to obey as mere subjects. In the latter case, a minimally just state may be a democratic state where almost everyone are "passive" citizens because of their lack of the means required to be independent ("active" citizen). Because they do not have sufficient means (lack the necessary ability) to live independently of others, they are dependent upon others' means (including powers) to gain access to a good livelihood. ${ }^{32}$ And, as we saw above, this means that until they rid themselves of this dependence through work, they may not, on this theory, have a right to vote. Again, the only legal condition that must be fulfilled in such a society where most people are poor, according to Kant, is, again, that "anyone can work his [one's] way up from this passive condition to an active one" (MM 6: 315). ${ }^{33}$ So, where the socio-economic conditions are such that many people can only obtain a livelihood by making themselves dependent on others in these ways (become servants), it must still be possible for them to work themselves out of such a condition.

Kant's judgement, therefore, is that although a lack of material independence for large groups of the population is a real worry for the minimally just state - a core issue to address as it reforms itself-as long as social climbing is not illegal and as long as any factors holding climbing back is based on considerations of human nature, the result does not deprive anyone of their basic rights. ${ }^{34}$ Hence, given this legal framework (of freedom), considerations of prudence (in response to considerations of our human nature, here complicated material circumstances of a people) can play their stabilizing role. Given the particular historical circumstances a state finds itself in, that is to say, and given that what is being stabilized is not inherently unjust and can be reformed into a more flourishing version, considerations of prudence are permissible or acceptable. Similarly, in the Doctrine of Right, Kant argues that notions of inherited "nobility of a country that is not under an aristocratic but a monarchical constitution is an institution... [that] may be permitted for a certain period of time and may even be necessary by circumstances. But it cannot be asserted that this estate can be established in perpetuity... a state has the right to alter its form (e.g. to reform itself into a republic ${ }^{35}$ )." (MM 6: 370) In other words, for reasons of prudence and history (such as a society evolving from a feudal social structure), it may be prudentially necessary for the leaders of the state to give certain historically powerful families certain inherited public privileges, such as being the only ones who can become monarchs, marry monarchs, or sit in the monarch's council or government. Since such a political leader's (monarch) exercise of power is still through laws of freedom (law recognizing each citizen's basic innate, private, and public rights) and since such a monarch (from a legal point of view) is a thoroughly public person (i.e. not a private person owning the nation's wealth as private property), such discretionary or despotic political uses of power (in response to actual circumstances) is permissible for a limited period. ${ }^{36}$ For example, such an arrangement may be necessary to stabilize a society coming out 
of periods of devastating civil wars. Nevertheless, this is not a legal-political practice strictly consistent with right-as it involves notions of hereditary (despotic) public power-and so it cannot be seen as a permanent, but only a "temporary" feature or an "accident" of the legal-political system (MM 6: 370). The notion of hereditary public privileges is contrary to an idea of the state reconcilable with each person right to freedom as spelled out through the idea of citizens as free, equal, and independent. Hence, as we will see more clearly below, ridding itself of hereditary public privileges is one main feature that reforming the minimally just state into its more flourishing versions consists in. ${ }^{37}$

\subsubsection{Reform: eliminating inherited public power and increasing social mobility}

Not just any monopoly on force can, then, yield political obligations on this account of justice, but something quite far away from a well-functioning civil society can do so. And the reason is, as suggested above, that as soon as the minimally just legal-political institutional framework is in place, what is required for the successful reform process to be possible also exists. The aim of such a reform process is to transform the minimally just state into a flourishing republic. As mentioned above, I believe that Kant's suggestions of what this actually means is usually explored by looking at some of his reflections in sections A through $\mathrm{D}$ of domestic public right in the Doctrine of Right, reflections that are supported by relevant remarks also in other texts. More specifically, I start by engaging Kant's discussions of reforming the tripartite, public authority itself (section $\mathrm{A}$ ), including the reform of public offices and dignities (section $\mathrm{D}$ ), before proceeding with a discussion of Kant's notion of socio-economic mobility (sections B \& C). I will use the cases of the United Kingdom and Norway to illustrate some of these points.

\section{a) Reforming the Pubic Authority: Ridding It of Inherited Power}

The issue of how to reform the public authority itself is one of the topics Kant discusses in section A of the Doctrine of Right (MM 6:318-323), and it is also a topic he returns to towards the end of his discussion of public right (MM 6: 339-42) and in an appendix added after the publication of the Doctrine of Right (MM 6: 369-772). As mentioned earlier, Kant thinks that all we can require of the minimally just state is that the public authority is tripartite (legally distinguishes between the legislative, judiciary, and executive authority institutionally and functionally), representative (understand the public authority as a public, not private authority), and that it exercises its public authority by analysing legal-political issues through the laws of freedom based on the related ideas of citizens' basic innate, private, and public rights. It is in virtue of these features that the minimally just state realizes public authority in terms of a "system representing the people" and that restricts exercises of freedom only in the name of freedom by subjecting interactions to laws of freedom (only).

One core problem with a state that is only minimally just in this way, however, is that the operations of the legal-political institutions depends on one, a few, or some person(s) since it is only one, a few, or some persons can be active citizens and so can hold higher public office, and especially the sovereign (legislative) power (whether a king, an aristocracy, or a group of citizens in a democracy) (6:340). The state is not, in other words, functioning properly as a self-governing republic in all its legal-political institutional operations yet; some aspects of how it actually functions are despotic in nature. As noted above, this lack of proper public self-governance-these despotic elements - may be something we simply must accept for reasons of prudence for a limited period of time; it may be the best or only way to take the first steps out of a situation of civil war with its sheer brutal, devastating, and absolutely destructive violence. Yet, it is clear that this is not a condition we can envision as sustainable and justifiable in perpetuity, since the actual functioning of the highest public power is in tension with each person having an innate right to freedom. That is to say, 
the form of the republic is not properly realized in such a constitutional document, by which, as we will see more clearly below, Kant means that the state always has the right to seek to rid it of any notions of inherited (despotic) public power and replace this with various kinds of merit-based considerations - or reform the minimally just republic (with many imperfectly republican or despotic, actual institutional principles) into a flourishing ideal of it (where the republican ideas of public self-government infuse the whole, actual function of the legal-political structure and its supporting public culture).

As we seek to reform our imperfect states, then, Kant keeps the worries concerning stability for the right reasons (being able to maintain the minimally just monopoly on coercion and yet develop it peacefully into something better) close at heart. This is, in my view, also why Kant proposes that the transforming of the sovereign authority must be a peaceful, consensual legal transformation-not on to be imposed by force from the top or "by the people acting as a mob." (6:340) Relatedly, Kant is quite clear that as the person or persons vested with sovereign power seeks to reform the sovereign authority, they cannot simply choose to

\begin{abstract}
... reorganize itself from one of the three forms into another, as, for example, aristocrats agreeing to submit to autocracy or deciding to merge into a democracy, or the reverse, as if it rested on the sovereign's free choice [freien Wahl] and discretion which kind of constitution it would subject the people to. For even if the sovereign decided to transform itself into a democracy, it could still do the people a wrong, since the people itself could abhor such a constitution and find one of the other forms more to its advantage. (MM 6:340)
\end{abstract}

In other words, as those actually entrusted with sovereign power seek to improve the institution of the sovereign (legislative) power (in the ways they know, insofar as they are committed to justice, that they ought to do) and, of course, the rest of the public authority, they must work with the people in so doing. I take it that there are two main, complementary reasons for this: First, what the public officials are trying to do is to enable true freedom for the people such that inheritance does not determine who actually ends up being entrusted with sovereign (public) authority, but also so that everyone can take direct, active part in the operations of the public authority through informed, public discussions and through holding other public offices. Consequently the first step here must be giving the people a real say about what kind of form of state they want, including whether or not they want to keep the one they have. For example, a people may want to keep the monarchy since they find that the royalty fulfils a certain, important role with regard to political stability, and they may find that it is part of the nation's history that they would like to continue, at least for now and until a good way of transcending it can be found. Second, changes in the basic legal-political structure concerning its basic form of state involves a dramatic change from something that works (at least minimally, given the people's particular history and circumstances) to something that might not work and with which the state and its people are not yet familiar; it is, in other words, a risky project. Such an undertaking may easily do much more bad than good_radically destabilize the state—and so it is something those vested with public authority want to do with the people on their side or in response to the people becoming increasingly vocal about this change being what they want. ${ }^{38}$

It is important to remember, then, that the main aim is to make the actual operations of the public power truer to the idea of the state, namely such that the public authority is the means through which we act so as to enable rightful interactions between us as free, equal, and independent. The public authority, in other words, is not yet another private person, but it is, ideally, a representation of an "us" through which we act so as to bring about a kind of interaction we cannot in principle enable as individual private persons (regardless of how virtuous we individually strive to be). Hence, the main aim is to ensure that the public authority—or the legal-political institutional force-is not something linked to any particular person or family (inherited power), but is an authority with which any one of us can be entrusted as we become capable. And being entrusted with it means being entrusted to do our very best to ensure that the legal- 
political institutional system as a whole functions as it should and so become increasingly trustworthy for each and all. In addition, of course, it is only prudent, and hence actually stabilizing, to give certain families such privileges that do not track the family members' (or people's) actual ability (merit) to hold public offices if we find ourselves in certain extreme, unstable circumstances where these families actually are crucial to stabilize the situation. If one lets such practices concerning who is entrusted with public offices continue, as Kant says, they will "fall into the hands of sheer incompetence" (MM 6: 328); as conditions become better, there are no good reasons not to let the election or appointment to these offices track merit (actual, proven ability). Moreover, as we keep reforming our system, we do not want to get rid, but rather further develop the public officials' ability to reason as our representatives, namely to analyse legal-political issues in terms of each citizen's basic rights (innate, private, and public rights). To do this, of course, we also need to strive towards a legal-political culture where such reasoning is expected and encouraged in public discourse. ${ }^{39}$

Kant was, if not the first, then among the first to give a thoroughly freedom-based, rather complex account of public reason. Public reason includes what we saw above as the kinds of ideals that we, as citizens of liberal states, must hold those entrusted with public authority accountable to, as well as, of course, the ideals those vested with public power must uphold as they reason and uphold the rule of law (its positing in general terms, its application in particular cases, and its enforcement). In addition, however, public reason also concerns those who hold lower public offices and the ways they are required to reason (in that capacity), namely in ways determined by the public policies constitutive of their public office-something Kant slightly confusingly calls "private reason" in his "What Is Enlightenment?" essay. ${ }^{40}$ In section D of domestic public right, Kant undertakes the question of how to reform the minimally just state into a civil condition (true republic) by addressing the issue of how to reform lower level public offices and dignities (MM 6: 238-30). According to Kant, the sovereign authority has the right to distribute both public offices (or "salaried administrative positions") as well as "dignities, which are eminent estates without pay, based on honor alone" (MM 6: 328). ${ }^{41}$ As with his discussion of the tripartite sovereign authority, central to Kant's analysis regarding how to reform a minimally just state's system of public officials lays in the idea of ridding the system of hereditary positions and honors. On the one hand, for the same reason that political prudence (stability) may have been a reason why some were given such positions and honors originally (when the state established its minimally just monopoly on coercion), ${ }^{42}$ prudence is also one major reason for giving it up as the situation improve. ${ }^{43}$ On the other hand, of course, we want to rid the system of such elements because they are inconsistent with right; no one is born an official or as more equal than others-and consequently, he argues, we correct this mistake by

$\ldots$ letting them [hereditary privileges] ... lapse and not filling vacancies in these positions... So it has a provisional
right to let these titled positions of dignity continue until even in public opinion the division into sovereign,
nobility, and commoners has been replaced by the only natural division into sovereign and people. (MM 6: 329)

I don't believe that this means that we cannot or should not maintain notions of public dignities. Rather, again, the idea is that what we want to rid the system of is notions of inherited public dignity (since this is inconsistent with the basic idea of all having innate dignity as a human being, as expressed in the idea of the innate right to freedom). The only conception of public offices consistent with the idea of each citizen having a right to freedom is one that says that everyone can work their way into any public position, even if actually being able to do so will depend to some extent variable factors like talents and luck. As Kant says in the Doctrine of Right, "the intention of the state... requires that everyone be able to rise from lower to higher offices." (MM 6:328) Of course, as we also saw above, the speed of this process and exactly how we go about changing it is a somewhat open question, and one that requires sound political judgment concerning how to ensure that we can achieve stability for the right reasons - now and in the future. To use the UK as 
an example, the institution of the Crown (usually on the recommendation of the Parliament) every year officially recognizes a number of British persons for their perceived outstanding public contributions to the nation—as artists, scholars, soldiers and military leaders, industrialists, charity workers, teachers and so on-by conferring various titles on them, such as damehood or knighthood. Again, Kant sees nothing wrong with this_-quite the contrary—but believes that although one might find oneself in a historical condition where actual access to such honors were obtainable only for the few, from certain families, as one's state becomes more well-functioning, they will simply track citizens' outstanding merit, service, or bravery to the country. And indeed, this seems to be the ideal currently informing how the UK now bestows such honors onto particular citizens.

To further illustrate some of the points above, let me stay with the example of reforms in the United Kingdom over the last few hundred years. So far, the UK has neither chosen to abolish its monarchy nor to abolish all elements of its aristocracy. Instead, the legal-political system has gone through many reforms (in addition, of course, to periods involving reversals and extreme violence) up until today when members of the highest and higher public offices increasingly no longer are chosen only from the nobility and aristocratic families, but on the basis of merit alone, and the sovereign (legislative) authority now lays with the people. Let me give some more details to fill in some of the important, relevant details here. For example, the highest public authority itself has been reformed into a parliamentary democracy supported by a constitutional monarchy, ${ }^{44}$ which includes a (largely and increasingly) independent judiciary, popular, democratic self-governance principles for the election of members of the House of Commons and the Prime Minister, and (later) non-democratic, yet merit-based election to the House of Lords. Concerning the institution of the monarch (or Crown) specifically, over the last few hundred years, although it is still inherited, it has been transformed into a representation of a non-partisan (politically neutral) public figure with very little political power (except, to some extent, in times of war and national crisis). The royalty today therefore mostly performs various public functions that are importantly non-partisan in nature, such as publicly recognizing the new Prime Minister (PM) or giving out (the aforementioned) national recognitions of merit and honor to citizens on behalf of the country. I don't think it's a stretch to say that the Crown aims to foster stability and healthy love of country - political emotions of a healthy, stabilizing kind - within the bounds set by the laws of freedom and as enabled by a legal-political process over which the monarch has no direct control. Correspondingly, this reform process has involved also transforming how the legislative process in the Parliament works, including how the House of Commons and the House of Lords came to exist and operate. Simplified, instead of being institutions whereby various powerful families (predominantly by heritance) gained access to influence the parliament's legislative process, participation in the House of Commons is decided through processes of popular, constitutional democracy, whereas participation in the House of Lords is decided by demonstrated merit concerning public affairs (gained through political activity or public, scholarly activity, for example). This reform process has therefore involved letting the House of Commons remain the main legislative body, whereto the members are chosen through popular elections and its leader (the Prime Minister) represents the political party supported by most votes, whereas the House of Lords has a critical, questioning function with regard to the politicians' legislative role in the House of Commons. Finally, the judiciary has become increasingly independent, where the rising from lower to higher courts aim to track the judges' merits, meaning their proven ability to apply the law and work towards increasing the legal system's overall ability to serve the people well. Hence, from a starting point where much of the public authority was only really accessible to those born into sufficiently and relevantly privileged families (inheritance), over time these elements have been eradicated by either democratic election or merit-based appointments having taken their place. 
I believe these ways in which the UK has developed are illustrations of what Kant means by how those vested with public authority — and everyone else through their engagement with it through public discussions-must seek to improve or reform it by making it function closer to the idea of the republic. So far, the UK has chosen a combination of various monarchical, aristocratic, and democratic elements in its public authority, and the many reforms (some of which are mentioned above) can be seen as aimed at reforming it into become more republican in its institutional form by ridding it of inherited privileges. Hence, the monarchic, non-partisan element has been separated from direct political power and instead functions as a constant dialogue partner for all sitting Prime Ministers, and it has become an institution also non-royals can marry into; the aristocratic elements (House of Lords) has become decoupled from inheritance and so has become a better way in which the people directly govern themselves by securing a critical, yet knowledgeable, informed voice that constantly raises questions to the popularly elected politicians (by being elected not by the politicians themselves, or those who have chosen them, but by the institution of the Crown); and the democratic elements for acting through representatives of political parties in the House of Commons, which determines who forms the government; and finally the largely merit-based, independence system for the judiciary.

The reason why the UK has chosen to do this rather than, say, simply getting rid the monarchy completely and turning the House of Lords into straightforward democratic, legislative body where the members are chosen in the same partisan ways as they are in the House of Commons, can plausibly be seen, I believe, as permissible reasons of political stability. The Crown (the monarchical institution) and the House of Lords are deemed stabilizing, non-partisan yet increasingly representative elements in the public legal-political structure - and, at least so far, as not easily replaceable, whereas the members of the legislative and government authorities are chosen through a representative, democratic process. And I take it that a good reason for also undertaking these reforming efforts rather slowly and for seeking a mix between popular and merit-based choices as well as allowing for some inheritance are concerns of our human nature. We seek to build legal-political institutional structures aimed at securing freedom and law for all and yet that has sufficient devices in them to increase the likelihood that they are stable too, given not only that we are the social creatures we are, but also how badly and destructively we so easily act. As Kant says in the Anthropology:

If one now asks whether the human species... is to be regarded as a good or bad race, then I must confess that there is not much to boast about in it. Nevertheless, anyone who takes a look at human behaviour not only in ancient history but also in recent history will often be tempted to take the part of Timon the misanthropist in his judgment; but far more often, and more to the point, that of Momus, and find foolishness rather than malice the most characteristic mark of our species. But... foolishness combined with a lineament of malice (which is then called folly) is not to be underestimated in the moral physiognomy of our species ... (A 7:332f)

The fact that we try to change the institutions somewhat slowly and by combining concerns of our histories with those of proven merit (including by popular choices) might, in other words, be viewed as attempts at increasing the chances that the operations our public legal-political institutions are wiser than any one of us are able to be on our own, including as we are entrusted with public offices. Moreover, given the very important stabilizing roles many monarchs have had, including during the historically recent World War II, it's also not far fetched, I believe, to suggest that among the important reasons many countries are not simply ridding itself of this institution is that it's considered unwise to do so before a good replacementsome other way of institutionally securing related stability and continuity through time- - has been found for these countries.

b) Reforming the Socio-Economic Systems 
Kant's comments on socio-economic systems are primarily found in his sections B and C of domestic public right (which, as we saw above, concerns various systemic arguments, including about poverty,) though he adds comments in the appendix to the Doctrine of Right (MM 6:369) and in the essay "Theory and Practice" (see below). And I have proposed that the state's guarantee of unconditional poverty relief is a minimal condition on a state's legitimacy and no state can make it illegal to work oneself out of a passive condition, whereas active citizenship for all is not such a minimal condition. Moreover, as we have also seen, Kant makes two types of arguments here, both of which can be seen as concerning our human nature, including problems concerning systemic (socio-economic related) inequality. I believe we can make sense of why Kant makes these kinds of arguments, although they may not be as good as Kant himself might have thought. As in the case of reforming the public authority, it seems particularly fruitful to look at relatively successful related reforms of some liberal states' socio-economic systems to illustrate the kinds of improvements Kant's position endorses. Before doing this, however, let us look at Kant's own reasoning concerning the possible link between active citizenship and human nature, including actual socio-economic conditions, in a little more detail.

In his "Theory and Practice" essay Kant makes the argument about having a right to vote in the following way:

The quality requisite to this [voting], apart from the natural one (of not being a child or a woman), is only that of being one's own master... hence having some property (and any art, craft, fine art, or science can be counted as property) that supports him - that is, if he must acquire from others in order to live, he does so only by alienating what is his and not by giving others permission to make use of his powers - and hence that, in the strict sense of the word, he serves no one other than the commonwealth. Here craftsmen and large (or small) landowners are all equal, namely each is entitled to only one vote. (TP 8: 296)

For Kant there seems to have been two main concerns informing his view that a lack of sufficient means for independence entails passive citizenship. One major concern for Kant on this issue was presumably a reflection of living in a period where Europe was coming out of a feudal ownership structure, and so a period characterized by a few very powerful landowners. Given this background and given Kant's basic commitment to everyone having an innate right to freedom, it is not so surprising that it is important for him to clarify that although a lack of property may make it impossible for one to vote, everyone with sufficient property-and he admits in a footnote here that it is difficult to determine "what is required in order to be able to claim the rank of a human being who is his own master [is]" (ibid.) — must be entitled to a vote, and only one. Hence, in this text Kant continues to emphasize that large, like small, landowners can only be seen as having one vote, just like all other active citizens (whoever are and are not included in this category of voting citizens).

A second concern that seems to be right under the surface here is the worry that since passive citizens are personally dependent upon others' powers to obtain a good livelihood—as revealed by them having to permit others to make use of their powers, like a domestic servant, rather than merely exchanging services or products of services (what is theirs) with them - their votes may be too easily unduly influenced or put pressure upon by the persons upon whom they are so dependent. This may be an especially important worry when the voting is not, as was typically the case in Kant's days, done by secret ballot. The problem, then, would be that those who were very rich might, in effect, even if not formally, end up with close to control over many votes and hence too much political power. ${ }^{45}$ The institution of secret ballots clearly dealt with the many of these worries regarding asymmetrical voting powers. ${ }^{46}$ In addition, as labor movements brought home, arguments concerning a lack of property (private property and skills enabled by education) are unsustainable over time in a liberal society. Of course, it is possible that the labor movements came into existence as workers became more independent; that is, as they were increasingly exchanging their services rather than giving others permission to use their powers and as public education, even if minimal at first, came into existence and literacy become more widespread. 
Finally, I believe that Kant wasn't quite as convinced by his argument concerning women's "natures" as he appears to be here; from the start, he was uncomfortable with his views and it seems fair to hold that he at least became increasingly aware of the fact that when it came to women's alleged inability to partake in public reason, it was his prejudices and not good judgement that influenced his thoughts about the issue. Still, the important point is that because Kant made sure that his position did not view such nature-based arguments as prior to or permitted to set the framework for arguments based on considerations of freedom, it was and is not hard to correct this mistake as a matter of theory. And as the women's movements have shown, it has also been possible as a matter of practice. Whether or not some group should be given the right to vote before they demand it, is, in contrast, perhaps not an unreasonable question; perhaps it is a fair or important consideration of stability (for the right reasons) in situations of transitional justice. In other words, perhaps movements such as the labor's and women's movements always will come before actual, stable reform; that they are what is needed to bring it about. This doesn't strike me as an implausible view. ${ }^{47}$

Still, what is the ideal regarding socio-economic justice that we should seek to realize as we reform our imperfect states? When commenting on the importance of making sure that the legal-political framework can be seen as acceptable also from the point of view of the poor, Kant emphasizes that the ideal must always that it is possible for this person to be "aware that, if he does not reach the same level as others, the fault lies only in himself ([his lack of] ability or earnest will) or in circumstances for which he cannot blame any other, but not in the irresistible will of others who, as his fellows subjects in this condition, have no advantage over him as far as right is concerned" (TJ 8: 293). Basically, then, I believe that as our states evolve and we build increasingly complex systems that are determining for how successful we are in exercising our rights—such as educational systems, economic systems, political systems etc.- there are two things we try to do with regard to socio-economic justice: on the one hand, we institutionally guarantee that any citizen's legal access to means as such is not dependent upon another private person's choice about the matter (by legally guaranteeing unconditional poverty relief), and on the other hand, we make sure that the systems that are freedom-determining are themselves accessible to all as free, equal, and independent, including so that we can, if we work hard, obtain any kind of public position by working within these systems. Securing this kind of social mobility, in other words, is internal to building complex societies where the exercise of rights becomes increasingly dependent upon access to systems.

These two principles, in my view, can be seen as part of the better bits of the Scandinavian welfare systems, and let me stick with the one I know the best, Norway. After World War II, Norway was a poor country, and not until the oil was discovered in the 1960s, did the situation change. Over the course of the next few decades, in turn, a so-called welfare state was established, which today means that at age 18 , all Norwegian citizens deemed capable of full legal responsibility are also materially independent. That is to say, at this age, all Norwegian citizens are independent of other private citizens, including economically from their parents in such a way that they can work themselves into any societal position, including public position. ${ }^{48}$ That is, at this age, all citizens obtain a (public) right to shelter, to health care, to educational loans and so on-to anything, in principle, that is deemed necessary to be able to work her- or himself into any type of position in society, including as required to hold any kind of public office. Of course, what she or he will be able to obtain will depend, as Kant also emphasizes, on factors such as luck and talent, and the system is far from perfect. The most important point for our purposes here, however, is that there are not only no legal restrictions upon what anyone can do (as compared to anyone else), but that the set of public rights that protects each citizen by providing the systemic opportunities that he or she needs to actually be able to obtain any level of education and, so, any societal, including public position. Moreover, even if a particular citizen fails in her or his endeavours, such as goes personally bankrupt, she or he cannot reasonable blame anyone else and there is systemic protection such that he or she will not end up on the street (she may, at 
most, end up back where the 18 year old is, to start again, from scratch with these basic welfare protections in place). In this way, these systems of public law aims to ensure not only that everyone is free and equal, but that her exercise of freedom is dependent only on law and so, in this way she is independent of other private persons and involves the opportunities for developing abilities needed to take active part in the public authority itself through informed public debates, including scholarly debates, and through holding public positions. This, I believe, is one way for states to realize the idea Kant is expressing by saying that the aim in liberal societies is to create conditions in which each citizen is free, equal, and independent since only such an idea is fully reconcilable with the idea of citizens as being subjected only to law (and not each other) and as governing themselves through public institutions as dictated, ultimately, by each person's innate right to freedom.

\section{CONCLUSION}

In this paper, I have suggested some ways in which Kant's sparse comments on self-governance may be developed in a way that is consistent with Kant's fundamental commitments concerning justice, including how an ideal theory must make space for various non-ideal considerations. In closing, let me note two further things. First, if this account is correct, then one important aspect of reforming these institutions must be to build mechanisms ensuring that the public authority is, exactly, exercised as it is should be. In other words, a major challenge for any public institution-building project is not only to fight corruption of economic sorts, but to ensure that those who are entrusted with public authority are not thereby given unchecked power. Kant himself emphasizes this by arguing that each power of the tripartite public authority must check on the two others, but we may widen this by arguing that the art of building such institutional frameworks include the need to make them transparent and accountable. Given the structure of the account, it follows that this is a particularly damning problem when building public institutions; after all, public institutions are supposed to the ultimate power-check on private interactions. The danger, in other words, is that the power-checking institution itself becomes corrupted; that those entrusted with the offices start treating them as their private power. This is not only a problem with regard to straightforward issues concerning self-interest, but also issues concerning power over others. For example, given the nature of the account, it is not surprising that some of most horrible failures in this regard have been seen in the liberal states' inexcusable failures to build systems of public, legal guardians (foster homes, homes for the mentally ill, and so on) in the right way. After all, the most alluring place to anyone who seeks thrills by dehumanizing others will be an unchecked dependency relation of personal power-and when we fail to construct our public authorities regarding legal guardianship in the right way, such a space is exactly what we create.

Second, notice too, that as we build the legal-political institutions constitutive of civil society, then it will typically be the case (for at least some time) that we, as a society, will not be able to guarantee safety and equal opportunities for social mobility. The states we inherit usually come with all kinds of dysfunctions tracking prejudices, power-abuses, and corruption—or much dysfunction both with regard to personal and socio-economic power. Hence, we want to be very careful about instituting new laws and institutions that give particular persons too much power or as punishing those on the fringes. To give two prominent examples: it is commonly the case that two areas where there is the most violence and abuse are those concerning sex work as well as the illegal economy surrounding drugs. Until recently, it seems relatively clear that much of the legal-political effort in these regards (in most countries) have focused on those selling sex and illegal substances on the streets. Hence, the effect of this practice of criminalization has been to make the already vulnerable citizens doubly vulnerable: they are not protected by anyone-in fact, even if the police interferes to protect these vulnerable groups (of sellers) against violence from buyers (or from those higher up the chain who control them), the police must also charge them with crimes (selling illegal 
services or substances). Although this is not a place to take a stand on which ways are better here-in general or in particular cases - I take it that these are among the main considerations that lead many to advocate not only the model, according to which these most vulnerable groups (the sellers on the streets) are not criminalized even if the buyers are, but also the model, according to which none of this activity should be criminalized since it makes it too hard to protect the sellers (the most vulnerable ones). Regardless of models, and in accordance with Kant's approach, I believe that what different sides in these debates can agree on is that the main efforts should be directed at improving the safety of the overall, socio-economic systemic conditions facing these sellers, including exit options for those involved, such that engaging in sex work or in the selling of strong, narcotic drugs on the streets are not the main or only choices (for securing a decent income) ever facing any one citizen.

\section{NOTES}

1. Thanks for very useful feedback to Eric J. Miller, Lars Vinx, and the audiences at the following conference and workshops: AMINTAPHIL 2014 Conference on Immigration and Citizenship, Chapman University, Oct. 9-12, 2014; workshop “Political Representation,” Universidade Federal da Bahia, Salvador, Brazil, Aug. 18-22, 2014; the Department of Philosophy, Arizona State University, colloquium, May 2, 2014; the conference "Kant and Republicanism," Cluster of Excellence "Formation of Normative Orders" and Hamburg University, 8-10 April, 2014.

2. Throughout this essay, I refer to all Kant's works by means of the standard Prussian Academy Pagination as well as one or two letters to make it easier for the reader to remember which work this pagination refers to, such as ' $M M$ ' for The metaphysics of morals. All the works referenced in this paper can be found in these collections of Kant's work: "Anthropology from a pragmatic point of view" (KANT, 2007); Practical philosophy (KANT, 1996a); Religion and rational theology (KANT, 1996b).

3. The historically most significant legal positivist position that considers itself at least very Kantian, is still, I believe, Hans Kelsen in Pure theory of law (KELSEN, 2009).

4. For an overview over many of the distinct approaches to Kant's legal-political philosophy, see EBELS-DUGGAN (2012), as well as VARGEN (2014a).

5. I'm simplifying Kant's argument somewhat here since he does believe that shame is a social power that can deprive others of what is theirs, namely their rightful honor. For more on this point, see, for example, VARGEN (2010a).

6. I expand on this argument in VARDEN (2012a).

7. For an overview over the secondary literature on these points, see VARDEN (2014a).

8. From this point onwards, those who go in more libertarians directions simply argue that the state therefore does exactly what individuals ought to do in the state of nature (regulate their interactions by means of the principles of private right), whereas those who go in more legal positivist directions argue that the state has rather unlimited discretion with regard to how it specifies rights.

9. How one analyzes these issues becomes determining for whether or not one thinks that the state's special role is fundamentally simply enforcing the rules privately determined in the state of nature (i.e. the state's enforcement function), or also regarding the specification (legislative function) and application (judicial function) of the principles of private right.

10. I'm particularly grateful to Lars Vinx for discussion on these points. 
11. I'm adding the "one's" here since I believe the best translation of Kant's original German would render the text gender neutral (and not male as Mary Gregor's translation has it) in English. I've written more on these passages in Kant, including as it related to women, in my "Kant and women" (VARDEN, 2015) and "Kant and dependency relations: Kant on the state's right to redistribute resources to protect the rights of dependents” (VARDEN, 2006).

12. Again, for more detail on these interpretive disagreements in the secondary literature, see VARDEN (2014a).

13. My first defense of this kind of approach was in my doctoral dissertation, the first publication from which is "Kant's non-voluntarist conception of political obligations: why justice is impossible in the state of nature" (VARDEN, 2008). For obvious reasons, the most prominent other defender of such an approach is (my dissertation advisor) Arthur RIPSTEIN (2009). The main difference between our views is that Ripstein formulates the need for the state in terms of problems of unilateral acquisition and assurance, whereas I do it in terms of two types of indeterminacy problems (specifying laws and applying laws) and assurance. I believe that the two positions are not incompatible, however: the main difference is that Ripstein focuses on how, when we arrive (as we usually do) in different times in a territory, we acquire things (provisionally) by unilateral force, whereas in my piece I focus on the problems of indeterminacy arising when people arrive at the same time. I believe this difference is deceptive, however, because the problem of unilateral acquisition (as such) is only a problem of justice for Kant if there is no one specification of the laws at the general and applied level. And since Kant (against, for example, Locke's proposal on the issue) denies that there is one such (unique and correct) specification and if his argument works, only then is it the case that one's enforcement of one's choices about this matter is to subject those with whom one interacts to one's choices and not to universal law. (Of course, if Locke is right that there is one way to specify the laws (of nature) generally and in particular cases, then one can enforce, for example, the "enough-and-as-good proviso" without thereby subjecting anyone else to one's unilateral, arbitrary and hence unjustifiable choices. In this scenario, such an enforcement is to subject everyone to the universal laws of nature.) I raise Kant-inspired objections to Locke's and Lockean related conceptions of the natural executive right and private property relations in VARDEN (2012b).

14. My original piece on this topic - 'Kant's non-absolutist conception of political legitimacy: how public right 'concludes' private right in 'The Doctrine of Right”' (VARDEN, 2010b).

15. I make this argument in VARDEN (2006) for the first time. I respond to Pauline Kleingeld's criticism of my position in VARDEN (2014b).

16. I show this in relation to Rawls's theory of justice as fairness as well as Robert Nozick's rightwing libertarianism in my "Rawls vs. Nozick vs. Kant on domestic economic justice" (VARDEN, forthcoming).

17. What Kant in the Religion calls the "original predisposition to good in human nature." (R 6: 26-28)

18. What Kant in the Religion calls the "the propensity to evil in human nature." (R 6: 28-32)

19. Cf. TP 8: 292: "They [all citizens] are... equal to one another as subjects; for, no one of them can coerce any other except through public law (and its executor, the head of state), through which every other also resists him in like measure..."

20. I'm grateful to Lucy Allais for this useful turn of phrase.

21. The original German word used by Kant here is "recht-liebend," which is why I have replaced Mary Gregor's translation ("law-abiding") with "law-loving."

22. On this point, I believe Kant agrees with Locke: not acting on prudential reasons reveal that we're acting in stupid ways, but they do not reveal that we're committing injustice. Hence, to justify the coercive establishment of the state, only ideal reasons will be sufficient on the ideal account; on such an account we need to show that refusing to enter civil society is to refuse the possibility of rightful (just) interactions with others. Of course, if this is the case, then we have reason to be suspicious of any interpretation that makes considerations of prudence essential for key arguments, such as the reason why we need to establish states, to go through. 
23. Obviously to justify this claim of Kant's is a larger project, beyond what I can and should do here (as I only want to indicate Kant's basic take on these issues to justify my interpretive assumption).

24. In the Anthropology, Kant calls these the "technical," the "pragmatic," and the "moral" predispositions (A 7:322-25).

25. Robert Louden ((LOUDEN, 2011)) is probably the one who has written the most on Kant's anthropology. See for example his Kant's human being: essays on his theory of human nature, but Susan Meld Shell (SHELL, 2009) has also engaged the topic quite extensively, such as in her Kant and the limits of autonomy. I deal with aspects of his anthropology in my "Kant and women" (VARDEN, 2015) and "Kant and moral responsibility for animals" (VARDEN, forthcoming).

26. For Kant's descriptions of some of the European peoples, see (A 7: 311-321).

27. It's a little hard to follow Kant here given the way in which he talks of animality and "pure" humanity here. To make it easier to understand, he could have written that the capacities to animality and humanity are existentially very important, and with the capacity to humanity there is necessarily the possibility of choices (since this capacity requires reason, albeit not practical reason). Hence, it is tempting for us not to engage others in the way that "pure" humanity would require us to do, which is when we consider each other as having "equal worth" (R 6:27), but instead as having unequal worth. In addition, of course, morality as such — what is justifiable to all, merely in virtue of being morally responsible persons - cannot possibly be deduced from these two predispositions since morality inherently is enabled by the third predisposition, namely to personality. Hence, Kant argues in this quote, these bad ways of doing religious instruction is terribly tempting for being such as us, but also profoundly confused.

28. Nationalism can be bad in much more horrifying ways than this, of course. For one such analysis, see VARDEN (2014c).

29. For the purposes of this paper, I have decided to set aside the related work in relation to section $\mathrm{E}$, on punishment.

30. I'm grateful to Arthur Ripstein (in conversation) for this way of describing the structure of Kant's thinking.

31. Obviously, exactly how one views Kant's account of public right determines how many of these specifications one accepts. As mentioned above, engaging this dispute-on the nature of public right in Kant's "Doctrine of Right" - is beyond what I need to engage here. For example, insofar as one accepts that Kant does maintain that there are innate, private, and public right principles constitutive of the idea of the state, one can agree on the general point here and disagree on some of the details.

32. As mentioned above, and as argued elsewhere, I believe that the state's guarantee of unconditional poverty relief is a minimal condition on a just state. Hence, without such a provision, the state is not even minimally just. This is why I write "good livelihood" here, rather than, say, "survival."

33. This is emphasized by Kant many places. For example, in "Theory and Practice" he says that "From this idea of the equality of human beings as subjects within a commonwealth there also issues the following formula: Every member of a commonwealth must be allowed to attain any level of rank within it (that can belong to a subject) to which his talent, his industry and his luck can take him; and his fellow subjects may not stand in his way by means of a hereditary prerogative (privileged [reserved] for a certain rank), so as to keep him and his descendants forever beneath the rank" (TP 8: 292, cf. 293f)

34. As also noted above, Kant suggests that there are can be two plausible sources of such lack of ability, namely "nature," which makes him suggest several places is not only why a minor or child never have the status of active citizens, but also women, as well as having the means to be one's own master, and so those who are excluded on this ground include "a domestic servant," "an apprentice in the service of a merchant or artisan," "the private tutor," and "the tenant farmer." (6: 314f, cf. TP 8: 294ff) 
35. This sentence is a little confusing, since it here looks as if Kant is saying that the republic is to be contrasted with aristocracies and monarchies - an as we've seen above, this just isn't his view. I believe one can read this two ways: either one can read this use of republic as referring to how the highest executive authority would be a president or one can read it as concerning how various non-republican (i.e. inherited) elements of the actual operation of the state can be reformed. In light of all the other textual evidence, including as we've seen it above, I believe the latter reading is the one intended here (though obviously it would be philosophically consistent to say either one).

36. This is consistent with how Kant emphasizes that the public authority (or state) in an important sense does not own anything as private property: "In accordance with concepts of right, the supreme proprietor cannot have any land at all as his private property (for otherwise he would make himself a private person). All land belongs only to the people (and indeed to the people taken distributively, not collectively), except in the case of a nomadic people under a sovereign, with whom there is no private ownership of land." (MM 6: 324) Hence, when the monarch is the only active citizen (lawmaker), then the monarch simply isn't a private person and also doesn't have private property at all, which also seems to have been the case historically in Western Europe at least. (The institutions of appanage and spaces that are deemed "for their private uses" don't seem to alter this basic fact: these decisions themselves are to be determined by the public authority. Indeed, even if an institution of monarchy is dismantled, it has remained to the public authority to decide which property the former royal family will be given to them as private property, now as private persons.)

37. I believe this is consistent with Kant's distinction in "Toward Perpetual Peace" between "the moral politician... who takes the principles of political prudence in such a way that they can coexist with morals, but not of a political moralist, who frames a morals to suit the statesman's advantage," as well as how he a little later says, for example, that "A state can already govern itself in a republican way even though, by its present constitution, it possesses a despotic ruling power, until the people gradually becomes susceptible to the influence of the mere idea of the authority of law.. .and thus is found fit to legislate for itself (such legislation being originally based on right)." (PP 8: 372)

38. Here is Kant's rather tricky text on this point: “The different forms of states are only the letter... of the original legislation in the civil state, and they may therefore remain as long as they are taken, by old and long-standing custom (and so only subjectively), to belong necessarily to the machinery of the constitution. But the spirit of the original contract... involves an obligation on part of the constituting authority to make the kind of government suited to the idea of the original contract. Accordingly, even if this cannot be done all at once, it is under obligation to change the kind of government gradually and continually so that it harmonizes in its effect with the only constitution that accords with right, that of a pure republic, in such a way that the old (empirical) statutory forms, which served merely to bring about the submission of the people, are replaced by the original (rational) form, the only form which makes freedom the principle and indeed the condition for any exercise of coercion, as is required by a rightful constitution of a state in the strict sense of the word. Only it will finally lead to what is literally a state. This is the only constitution of a state that lasts, the constitution in which law itself rules and depends on no particular person. It is the final end of all public right, the only condition in which each can be assigned conclusively what is his; on the other hand, so long as those other forms of state are supposed to represent literally just so many different moral persons invested with supreme authority, no absolutely rightful condition of civil society can be acknowledged, but only provisional right within it.

Any true republic is and can only be a system representing the people, in order to protect its rights in its name, by all the citizens united and acting through their delegates... But as soon as a person who is head of state (whether it be a king, nobility, or the whole of the population, the democratic union) also lets itself be represented, then the united people does not merely represent the sovereign: it is the sovereign itself. For in it (the people) is originally found the supreme authority from which all rights of individuals as mere subjects (and in any event as officials of the state) must be derived; and a republic, once established, no longer has to let the reins of government out of its hands and give them over again to those who previously held them and could again nullify all new institutions by their absolute choice." (MM 6: 340) 
39. If this is roughly right, notice the important similarities between this view of public reason and the one advanced by John Rawls from Political Liberalism (RAWLS, 1993) onwards.

40. We find the main arguments yielding his account in the Doctrine of Right (MM 6:238) as well as in the "What Is Enlightenment?" essay (WIE 8: 36-42) and the "Theory and Practice" paper (TJ 8: 289-307. See also Jonathan Peterson's (2008) interpretation of Kant's "private/public" reason distinction in his "Enlightenment and freedom”.

41. Kant also includes the right to punish in his list here, but since he turns to this issue in a separate section (section E), I also discuss it separately.

42. Kant says "The anomaly of subjects who want to be more than citizens of the state, namely born officials (a born professor, perhaps) may have crept into the machinery of government from older times (feudalism, which was organized almost entirely for war)." (6:328)

43. As mentioned above, unless one puts in place an idea of everyone being "able to rise from lower to higher offices" in light of their merit, one ends up with a system that will "fall into the hands of sheer incompetence" (6:328).

44. Given my purposes here, I'm doing my best to be as theoretically uncommitted as possible in this illustration. Hence I'm utilizing the UK's own, official descriptions here: http://www.parliament.uk/about/how/role/parliamentgovernment/. Also, I'm not of course saying that all of this happened peacefully—for example, James II did violently resist related reform efforts leading to the 1699 “Glorious Revolution”- but the royal family as such didn't (after James II was deposed, he was replaced by his own daughter, Mary II, together with William III) and the process could have proceeded without violent resistance from James II.

45. Obviously, the same worry could be raised with regard to the issue of women having votes; if they were so personally dependent on their husbands (including if it was in their natures that they would be so dependent), then all married men could end up with, in effect, two votes, and all unmarried ones only one.

46. I believe the practice of secret ballot started in Europe in the elections in France in 1795, and so two years after "Theory and practice" (1793) was published. If so, this could be the reason why Kant does not repeat this kind of argument in the Doctrine of Right (1797). In any case, the late 1700's/the 1800's was a period when various secret ballot acts passed in several states, and hence it seems reasonable to believe Kant was paying attention to these discussions in his thinking too.

47. I discuss this question in my paper "Kant and women" (VARDEN, 2015).

48. At least if we count the fact that one can marry the monarch, since the current King (Harald) and Crown Prince (Haakon) are married to non-royal citizens. (Interestingly, unlike the other monarchies in Europe, the first monarch of the last line (King Haakon) only agreed to take over as monarch (as part of a constitutional, representative democracy) when Norway seceded from Sweden in 1905 if the Norwegian people so chose. Hence, he was chosen by referendum (1905); a fact that seems consistent with how Kant envisions peaceful transitions involving the highest public offices, as described above.

\section{REFERENCES}

BYRD, B. S.; HRUSCHKA, J. 2012. Kant's Doctrine of Right: a commentary. Cambridge: Cambridge University Press.

Ebels-Duggan, K. 2012. Kant's political philosophy. Philosophy Compass, v. 7, n. 12, p. 896-909.

GUYER, P. 2000. Kant on freedom, law, and happiness. Cambridge: Cambridge University Press. 
KANT, I. 1996a. Practical philosophy. Translated and edited by Mary J. Gregor. New York: Cambridge University Press.

KANT, I. 1996b. Religion and rational theology. Translated and edited by Allne W. Wood and George di Giovanni. New York: Cambridge University Press.

KANT, I. 2007. Anthropology from a pragmatic point of view. Translated by Robert B. Louden. In: Anthropology, history, and education. New York: Cambridge University Press.

KAUFMAN, A. 1999. Welfare in the kantian state. New York: Oxford University Press.

KELSEN, H. 2009. Pure theory of law. New Jersey: The Lawbook Exchange.

LOUDEN, R. 2011. Kant's human being: essays on his theory of human nature. New York: Oxford University Press.

O’NEILL, O. 1996. Towards justice and virtue. Cambridge: CUP.

O’NEILL, O. 2000. Bounds of justice. Cambridge: CUP.

PETERSON, J. 2008. Enlightenment and freedom. The Journal of the History of Philosophy, v. 46, p. 223-244.

RAWLS, J. 1993. Political liberalism. New York: Columbia University Press.

RIPSTEIN, A. 2009. Force and freedom. Massachusetts: Harvard University Press.

SHELL, S. M. 2009. Kant and the limits of autonomy. Cambridge: Harvard University Press.

VARDEN, H. 2006. Kant and dependency relations: Kant on the state's right to redistribute resources to protect the rights of dependents. Dialogue, Montreal, v. 45, n. 2, p. 257-284.

VARDEN, H. 2008. Kant's non-voluntarist conception of political obligations: Why justice is impossible in the state of nature. Kantian Review, v. 13, n. 2, p. 1-45.

. 2010a. A Kantian conception of free speech. In: GOLASH, D. (Ed.). Freedom of expression in a diverse world. New York: Springer Publishing. p. 39-55.

. 2010b. Kant's non-absolutist conception of political legitimacy: how public right 'concludes' private right in 'The Doctrine of Right'. Kant-Studien, Berlin, v. 101, n. 3, p. 331-51

.2012a. A feminist, kantian conception of the right to bodily integrity: the cases of abortion and homosexuality. In: CRASNOW, S. L.; SUPERSON, A. M. (Ed.). Out of the shadows. New York: Oxford University Press. p. 33-57.

. 2012b. The lockean 'enough-and-as-good' proviso: an internal critique. Journal of Moral Philosophy, v. 9, n. 3, p. 410-22.

.2014a. Immanuel Kant - Justice as freedom. Philosophy of Justice, Netherlands, v. 12, p. 213-37. 
.2014b. Patriotism, poverty, and global justice: a kantian engagement with Pauline Kleingeld's Kant and Cosmopolitanism. Kantian Review, v. 10, n. 2, p. 251-266.

. 2014c. The terrorist attacks in Norway, July 22nd 2011 - Some kantian reflections. Norsk Filosofisk Tidsskrift, v. 49, n. 3-4, p. 236-259.

.2015. Kant and women. Pacific Philosophical Quarterly. Forthcoming.

. Forthcoming. Kant and moral responsibility for animals. In: ALLAIS, L.; CALLANAN, J. (Ed.). Kant on animals. Oxford: Oxford University Press.

. Forthcoming. Rawls vs. Nozick vs. Kant on domestic economic justice. In: FAGGION, A.; SÁNCHEZ, N. (Ed.). Kant and social policies. UK/US: Palgrave Macmillan. 